\title{
Tanniferous forage plants Agronomic performance, palatability and efficacy against parasitic nematodes in sheep
}

\section{Journal Article}

\section{Author(s):}

Häring, Dieter Adrian; Scharenberg, Anna; Heckendorn, Felix; Dohme-Meier, Frigga; Lüscher, Andreas (D; Maurer, Veronika; Suter, Daniel; Hertzberg, Hubertus

\section{Publication date:}

2008-03

\section{Permanent link:}

https://doi.org/10.3929/ethz-b-000011732

Rights / license:

In Copyright - Non-Commercial Use Permitted

Originally published in:

Renewable Agriculture and Food Systems 23(1), https://doi.org/10.1017/S1742170507002049 


\title{
Tanniferous forage plants: Agronomic performance, palatability and efficacy against parasitic nematodes in sheep
}

\author{
D.A. Häring ${ }^{1,2}$, A. Scharenberg ${ }^{3,4}$, F. Heckendorn ${ }^{5}$, F. Dohme ${ }^{3}$, A. Lüscher ${ }^{1}$, V. Maurer ${ }^{5}$, \\ D. Suter ${ }^{1}$, and H. Hertzberg ${ }^{5,6 *}$
}

\author{
${ }^{1}$ Agroscope Reckenholz-Tänikon Research Station ART, Reckenholzstrasse 191, CH-8046 Zurich, Switzerland. \\ ${ }^{2}$ Institute of Plant Sciences, Swiss Federal Institute of Technology, ETH Zurich, Universitätstrasse 2, \\ $\mathrm{CH}-8092$ Zurich, Switzerland. \\ ${ }^{3}$ Agroscope Liebefeld-Posieux Research Station ALP, Tioleyre 4, CH-1725 Posieux, Switzerland. \\ ${ }^{4}$ Institute of Animal Sciences, Swiss Federal Institute of Technology, ETH Zurich, Universitätstrasse 2, \\ $\mathrm{CH}-8092$ Zurich, Switzerland. \\ ${ }^{5}$ Research Institute of Organic Agriculture, FiBL, Ackerstrasse, CH-5070 Frick, Switzerland. \\ ${ }^{6}$ Institute of Parasitology, University of Zurich, Winterthurerstrasse 266a, CH-8057 Zurich, Switzerland. \\ ${ }^{*}$ Corresponding author: hubertus.hertzberg@access.unizh.ch
}

\begin{abstract}
Tanniferous forage plants can have beneficial effects on ruminant productivity and health (improved protein supply, bloat safety and antiparasitic properties). However, condensed tannins can also lower palatability, voluntary feed intake and digestibility. The aim of our interdisciplinary project was to generate basic knowledge on plant management, feed palatability and the antiparasitic properties of tanniferous forage plants for their practical application in agronomy, focusing on their usefulness in controlling gastrointestinal nematodes in organic farming. We found that Onobrychis viciifolia (sainfoin), Lotus corniculatus (birdsfoot trefoil) and Cichorium intybus (chicory) were suitable for cultivation under the given temperate climatic conditions, whereas Lotus pedunculatus (big trefoil) was soon outcompeted by unsown species. Growing the tanniferous plant species in a mixture with Festuca pratensis (meadow fescue) rather than in a monoculture had the advantage of increasing total dry matter (DM) yield (especially in the case of tanniferous legumes) and of reducing the DM proportions of unsown species. However, due to dilution by non-tanniferous F. pratensis, the tannin concentrations of mixtures were clearly lower and the seasonal fluctuations in tannin concentrations greater than that of monocultures. Across species, tannin concentrations were highest for O. viciifolia, followed by L. corniculatus and very low for C. intybus. Palatability of all tanniferous forages was comparable to that of a ryegrass/clover mixture when fed as dried forage and, when offered as silage, palatability of $O$. viciifolia was clearly superior to that of the respective ryegrass/clover control. Administration of dried or ensiled $O$. viciifolia reduced parasite egg counts in feces of lambs co-infected with the gastrointestinal nematode species Haemonchus contortus and Cooperia curticei. We conclude that $O$. viciifolia is the most promising among the tested tanniferous forage plant species due to its suitability for cultivation, its high tannin concentration, its high palatability and its antiparasitic activity even in dried or ensiled form.
\end{abstract}

Key words: condensed tannins, proanthocyanidins, forage cultivation, yield, silage, palatability, gastrointestinal nematodes, parasite control, sheep

\section{Introduction}

Recent experiments in agronomy and parasitology suggest that moderate dietary concentrations of condensed tannins can affect the health and performance of sheep and other small ruminants beneficially ${ }^{1-5}$. For example, condensed tannins were found to increase life weight gain, fecundity and wool production in sheep ${ }^{6,7}$. With regard to animal health, condensed tannins are known to diminish the risk of bloat, lower fecal worm egg excretion and reduce worm burdens of parasitized ruminants ${ }^{3,5}$. However, high concentrations of condensed tannins can have a negative 
impact on ruminants. They can lower palatability and digestibility $^{5,8}$ and, in extreme cases, they can lead to mucosal lesions 9 .

In an interdisciplinary project involving research on plant cultivation, animal nutrition and parasitology, we addressed key questions concerning the implementation of tanniferous forage plants as an alternative control strategy against gastrointestinal nematodes in animal husbandry: Which tanniferous species and cultivars (cv.) perform well with regard to agronomic properties such as yield, persistence and competitive ability? What are their concentrations of condensed tannins and what are the most important drivers of fluctuations in tannin concentrations under field conditions? How palatable are different tanniferous forage plant species in comparison to a ryegrass/clover mixture? How effective is the most promising plant species against gastrointestinal nematodes in sheep? Can tanniferous forages be conserved without losing their desirable anthelmintic properties?

\section{Plant Sciences and Forage Cultivation}

The expressions 'condensed tannins' or synonymously 'proanthocyanidins' summarize a large and chemically diverse group of phenolic polymers with the ability to bind proteins and other macromolecules. Apart from their strong affinity for proteins, condensed tannins can form complexes with metal ions and have radical scavenging properties ${ }^{10}$. The structure of condensed tannins consists of a linkage of a series of monomers based on flavan-3-ol nuclei or derivatives thereof ${ }^{11}$. Variations in the structure of condensed tannins (and supposedly of their bioactivity) can occur through differences in the number of monomers, the positions between which these monomers are interlinked, the oxygenation pattern of the monomers or the stereochemistry of the polymer ${ }^{11,12}$. Condensed tannins exist as water-soluble oligomers and as insoluble polymers ${ }^{10}$. Tanniferous plants usually contain mixtures of differently structured tannins rather than one specific type of molecule ${ }^{11,13}$. The quantity and structural composition of tannins vary between different tissues and can change during plant development ${ }^{13,14}$. Condensed tannins occur predominantly in woody plants but can also be found in some herbaceous plant species, for example in representatives of the Rosaceae and Fabaceae families ${ }^{11}$. Within plants, condensed tannins are concentrated in cell vacuoles $^{12}$ and usually occur in higher concentrations in leaves and reproductive organs than in stems and roots ${ }^{14}$.

The bioactivity of condensed tannins is thought to be a function of tannin concentrations defined as the ratio between consumed tannin and consumed protein or feed ${ }^{11}$ rather than of the absolute amount of consumed tannin. As a rule of thumb it has repeatedly been suggested that tannin concentrations below $50 \mathrm{~g} \mathrm{~kg}^{-1} \mathrm{DM}$ produce positive effects in ruminants, while concentrations in excess of $50 \mathrm{~g} \mathrm{~kg}^{-1} \mathrm{DM}$ affect the animal negatively ${ }^{1,4}$. Today's experimental evidence relativizes this rule to the extent that tannins from different sources may vary in their "potency ${ }^{5}$ and that it is likely that different thresholds need to be defined for different tannins and, thus, different forage plant species.

Genotypic and phenotypic variation of type and quantity of secondary metabolites have often been studied within the paradigm that their primary role is plant defensive and their effect on consumers detrimental. The accumulated experimental evidence for and against the so-called plant defense theory ${ }^{15-18}$ is equivocal ${ }^{19,20}$ and its usefulness for the practical application in agronomy disputable ${ }^{14}$. Previous studies of seasonal fluctuations of tannin concentrations in forage plants yielded conflicting results ${ }^{14,21-24}$ and mechanisms driving seasonal and developmental dynamics of tannin concentrations under field conditions are not yet well understood. Based on an experiment with potted Onobrychis viciifolia and Lotus corniculatus, it has been suggested that fluctuations in condensed tannin concentrations in harvestable aboveground biomass are functions of biomass proportions between tannin-rich leaves and tannin-poor stems in pure stands, and of biomass proportions between tanniferous and non-tanniferous plant species in mixed stands ${ }^{14}$. At present, it is unclear to what extent these hypotheses hold true under field conditions.

For a successful implementation of a gastrointestinal nematode control strategy based on tanniferous forage plants, it is essential that the tanniferous forage crop provides a high yield, has a high competitive ability and an elevated but predictable concentration of condensed tannins. Especially under low input conditions, the agronomic performances of species mixtures have been reported to be superior to those of monocultures. In comparison to monocultures, mixtures are often characterized by higher dry matter (DM) yields ${ }^{25}$, improved evenness of the seasonal growth patterns ${ }^{26}$ and increased resistance against weed invasion ${ }^{25}$. Until now, comparative assessments of agronomic performances of promising tanniferous forage plants and concurrent investigations of tannin concentration dynamics under field conditions have been scarce.

Therefore we evaluated yield, resistance to weed invasion and tannin concentrations of 12 cultivars of four commercially available, tanniferous forage plant species which were either sown in a monoculture or in a mixture with the grass species Festuca pratensis in a three-year field experiment. We put special emphasis on investigating to what extent potential seasonal fluctuations of condensed tannin concentrations in the yield can be attributed to shifts in the relative DM contribution of tanniferous plants to total DM yield.

\section{Animal Nutrition}

Palatability designates the sum of all physical and chemical characteristics of a diet that evoke appetite, such as olfactory, gustatory and tactile stimuli during foraging and chewing ${ }^{27}$. Repeated feeding of a particular diet 
enables an animal to anticipate potential nutritional and physiological postingestive feedbacks and eventually to develop a preference for or an aversion against $\mathrm{it}^{28}$. The perception of a diet, and subsequent feed preferences, vary among individual animals according to differences in physiology and experience ${ }^{29}$. Therefore, palatability and food preference are questions of physiological traits of the animal, of individual experience and of the feed quality of the forage in question in relation to the range of feeds available to the animal.

There is a wealth of evidence suggesting that condensed tannins in plants influence the voluntary feed intake, palatability and digestibility of the fodder ${ }^{2,4,5}$. It is thought that the importance of condensed tannins in animal nutrition lies mainly in their ability to bind proteins. For example, the astringent taste of tanniferous plants is a consequence of the binding of tannins to salivary proteins. The lower true digestibility of feed proteins, the increase of the excretion of endogenous protein in pigs ${ }^{30}$, and the lower ruminal protein degradability combined with a lower apparent digestibility in ruminants ${ }^{31}$ are results of the binding of tannins to feed protein and endogenous proteins. While protein precipitation in the intestine lowers amino acid availability and affects the ruminant adversely, protein precipitation and protein protection from microbial degradation in the rumen can be desirable and beneficial to the animal $^{32}$. The binding of condensed tannins to protein in the rumen $(\mathrm{pH} \mathrm{6-7)}$ lowers ammonia production and reduces the metabolic strain of the liver (2). Furthermore, it enhances the protein flow towards the small intestine and, provided the tannin-protein complexes dissociate in the more acid medium of the abomasum $(\mathrm{pH}<3)$, raises the animal's supply of essential amino acids ${ }^{5,33}$. An improved protein supply of the ruminant is one of the possible pathways leading to an increased tolerance of ruminants to gastrointestinal parasite infections ${ }^{3,34}$. In addition to the likely impact of condensed tannins on nitrogen metabolism, tannins may also affect the mineral supply of the animal 35,36 . For the practical application of tanniferous forages in livestock production, e.g. as an alternative nematode control strategy, administration of forage plants in a conserved form (either as dried or ensiled forage) is of great interest. In previous experiments, condensed tannins were reported to depress proteolysis thereby reducing the loss of forage protein during the ensiling process ${ }^{37}$. Furthermore, it was observed that ensiling reduced tannin concentrations of sorghum ${ }^{38}$. Up to now, little is known about the effect of ensiling on the palatability of tanniferous forage plants.

Feeding trials provide an ideal means of obtaining a brief and summary-like answer to the complex question of whether or not a certain (tanniferous) forage plant species is suitable for its consumer, and allow an assessment of voluntary feed intake and possible side effects of the feed. In this study, we aimed to identify the most promising tannin-containing plant species and conservation method in terms of the wethers' acceptance and, thus, palatability of dried or ensiled $O$. viciifolia, L. corniculatus and Cichorium intybus in relation to a dried or ensiled non-tannincontaining ryegrass/clover mixture, respectively.

\section{Parasitology}

Infections with gastrointestinal nematodes represent a major constraint on the profitability of sheep, goat and cattle production. This is particularly pronounced in lowinput farming where animals are grazing on pastures, in contrast to intensive production systems in which access to pasture is limited or even absent ${ }^{39}$. The organic farmer is confronted with the problem of (i) reducing the infection pressure to an acceptable level and (ii) having largely to resign himself to the use of conventional anthelmintic drugs in order to keep within the organic guidelines. As complementary approaches to control gastrointestinal parasitism of small ruminants, such as the exploitation of the genetic resistance of livestock ${ }^{40}$, biological control of the free-living larval stages in the feces by means of nematophagous fungi ${ }^{41,42}$, manipulation of grazing management $^{43}$ and dietary supplementation with protein ${ }^{44}$, were each only partially effective, the control of endoparasites remains largely based on the application of synthetic anthelmintic drugs. The development of gastrointestinal parasite populations resistant against most of the currently available anthelmintics further highlights the need for alternative parasite control strategies ${ }^{45}$.

Recent experiments with tanniferous forages administered to sheep and goats infected with gastrointestinal nematodes yielded promising results ${ }^{3}$. Tanniferous forages that were grazed, or freshly administered, to naturally or artificially infected animals often resulted in a decreased fecal egg count (i.e. the number of worm eggs per gram feces of the host), which was sometimes accompanied by a reduction of worm burden (i.e. the number of adult worms) or reductions in worm fecundity. The potential of condensed tannins as an antiparasitic agent has been substantiated by various in vitro and in vivo experiments: condensed tannins were found to reduce the parasites' motility, possibly by binding to surface proteins, to exert a toxic effect on parasite eggs, larvae or adult worms and to hinder larval development ${ }^{3,46}$. Alternatively or complementary to these 'direct effects', condensed tannins can exert indirect effects. For example, they may help to improve the host's immune response to parasitism (i.e. resistance) by enhancing the ruminant's supply of proteins and essential amino acids ${ }^{3}$.

Administering tanniferous forages to parasitized ruminants in a conserved form, either as hay or silage, could potentially enhance the practicability and efficacy of the treatment. However, experiments with conserved forages remain few. Therefore, we tested the feeding of $O$. viciifolia hay and silage, respectively, to lambs co-infected with Haemonchus contortus and Cooperia curticei in comparison to non-tanniferous control feeds ${ }^{47}$. 


\section{Methods}

\section{Agronomic performance of tanniferous forage plants}

We assessed the yield, the competitive ability and the tannin concentration in the yield of 12 cultivars of four tanniferous plant species sown in monoculture or in a mixture with a non-tanniferous grass species. Plant performances were observed from sowing in spring 2004 until the last harvest in May 2006. The experiment included O. viciifolia (sainfoin, fam. Fabaceae: ecotype Alvaschein, commercial seed, cv. Visnovsky), Lotus pedunculatus (big trefoil, fam. Fabaceae: cv. Grasslands Maku, cv. Barsilvi, cv. Grasslands Sunrise), L. corniculatus (birdsfoot trefoil, fam. Fabaceae: cv. Odenwälder, cv. Lotar, cv. Oberhaunstädter), Cichorium intybus (chicory, fam. Asteraceae: cv. Grasslands Puna, cv. Forage Feast, cv. INIA Lacerta). For the mixtures, we selected $F$. pratensis (meadow fescue, fam. Poaceae: cv. Preval), a grass suitable for low-input farming with a high nutritive quality but with limited potential as a competitor.

The field experiment was done at Agroscope Reckenholz-Tänikon, Research Station ART, in Zurich, Switzerland $\left(47^{\circ} 26^{\prime} \mathrm{N}, 8^{\circ} 30^{\prime} \mathrm{E}\right)$. The block experiment (three blocks) was sown with 'plant species' as the main plot factor, 'cultivar' as the subplot factor and 'purely sown versus mixture' as the sub-subplot factor ${ }^{48}$. Within each main plot (species), the cultivars were assigned randomly to pairs of sub-subplots with an area of $9 \mathrm{~m}^{2}(1.5 \mathrm{~m} \times 6 \mathrm{~m})$ each. On one of these plots the tanniferous cultivar was sown in monoculture; on its neighboring plot, it was sown in a mixture with the grass $F$. pratensis. To complete the design, each block contained two grass monocultures of $9 \mathrm{~m}^{2}$ size (i.e. F. pratensis cv. Preval). Sowing densities of monocultures of $O$. viciifolia, $L$. pedunculatus, $L$. corniculatus, $C$. intybus and $F$. pratensis corresponded to 180,18 , 18,4 and $25 \mathrm{~kg} \mathrm{ha}^{-1}$ of germinable seed, respectively. For the mixtures, we replaced $40 \%$ of the respective tanniferous plant species seed by $40 \%$ of $F$. pratensis seed (i.e. $25 \mathrm{~kg} \mathrm{ha}^{-1} \times 40 \%=10 \mathrm{~kg} \mathrm{ha}^{-1}$ ). Per block, one grass sward and all plots containing legumes (i.e. plants of the family Fabaceae with the ability of $\mathrm{N}_{2}$-fixation by means of symbiotic rhizobia) were fertilized with only $25 \mathrm{~kg} \mathrm{Nha}^{-1}$ after each harvest. The remaining grass monocultures and the chicory plots were fertilized with $50 \mathrm{~kg} \mathrm{Nha}^{-1}$ after each harvest.

Swards were harvested twice in the year of sowing (i.e. 2004), four times in 2005 and a last time in spring 2006. On each of these occasions, three bands of $10 \mathrm{~cm}$ width were cut across every sward at $7 \mathrm{~cm}$ above ground level for an assessment of the botanical composition of the harvest and a quantification of its tannin concentration. A random subsample (one-third) of that plant material was immediately put on ice for transportation and dried at $60^{\circ} \mathrm{C}$ for $48 \mathrm{~h}$ as soon as possible, ground to pass through a $0.75 \mathrm{~mm}$ sieve, and stored in the dark at room temperature before it was analyzed for condensed tannins using a butanol-HCl-assay with a $L$. pedunculatus standard ${ }^{49}$. The remaining twothirds of the plant material were separated into 'sown tanniferous species', 'sown $F$. pratensis' and 'unsown species'. The separated plant fractions were dried at $100^{\circ} \mathrm{C}$ for $24 \mathrm{~h}$ to calculate their relative contributions to the total DM yield. After collecting the botanical samples, swards were harvested by machine, $7 \mathrm{~cm}$ above ground level and the total DM yield of each sward was determined.

\section{Feed palatability}

In two consecutive but independent experiments of 20 days' duration each, the palatability for wethers of three tanniferous forage plant species (i.e. O. viciifolia, $L$. corniculatus and $C$. intybus) was tested in comparison to a control feed consisting of a ryegrass/clover mixture. In a first experiment, feeds were offered as dried forages; in a second experiment they were offered as silages.

$O$. viciifolia cv. Visnovsky, L. corniculatus cv. Oberhaunstädter, $C$. intybus cv. Grasslands Puna and a ryegrass/ white clover/red clover mixture were grown in 2003 at Agroscope Liebefeld-Posieux, Research Station ALP, Posieux $\left(46^{\circ} 46^{\prime} \mathrm{N}, 7^{\circ} 06^{\prime} \mathrm{E}\right)$, Switzerland. The tanniferous forages were topped once at the beginning of July, harvested in August and ensiled in 700-liter containers. Second harvests were taken at the end of September $(C$. intybus) or in mid October (O. viciifolia, L. corniculatus), respectively, and dehydrated at $30^{\circ} \mathrm{C}$ to a water content below 10\% using a special drying system (Physitech, Wabern, Switzerland) that minimized the loss of tanninrich plant leaf material. The non-tanniferous control mixture was taken from the fourth cut at the end of September from a ley and was likewise dried or ensiled. The tannin concentrations of the forages were analyzed using a butanol-HCl-assay with a $L$. pedunculatus standard $^{49}$.

The experiment involved three groups of adult Oxford wethers $(n=6)$ corresponding to the three tanniferous forage plant species. On average, wethers were $4.1 \pm 1.8$ years old and had a weight of $87.6 \pm 7.2 \mathrm{~kg}$; they were individually housed in pens. Wethers were offered a choice between the respective tanniferous forage and the control feed, which were presented simultaneously in two separate boxes. During the first 10 days of each experiment, the diets contained $110 \%$ of the maintenance energy requirement and were given in equal portions twice a day. The maintenance energy requirement $\left[\mathrm{ME}_{\mathrm{m}}\right.$ in $\mathrm{MJ}$; equation (1)] was calculated as a function of the life weight (LW) of each animal and expressed as metabolizable energy ${ }^{50}$ :

$$
\mathrm{ME}_{\mathrm{m}}=0.38 \times \mathrm{LW}^{0.75}
$$

During the second 10 days, the sheep received half of the experimental diets $\left(55 \% \mathrm{ME}_{\mathrm{m}}\right)$ at $07: 00 \mathrm{~h}$ and additionally low-quality hay $\left(100 \% \mathrm{ME}_{\mathrm{m}}\right)$ at 16:00 h. Individual foragespecific feed intake was measured twice a day: once after a short evaluation period $t(t=7.5 \mathrm{~min}$ for ensiled forage and $t=15 \mathrm{~min}$ for dried forage) and once in the afternoon at 
Table 1. Total yield, DM proportion of sown species, DM proportion of tanniferous species and tannin concentration of total yield harvested in the year 2005 (mean \pm SE; $n=3$, swards were cut four times in 2005). All cultivars were sown in 2004 either as pure stands or in mixture with $F$. pratensis. CT, condensed tannin.

\begin{tabular}{|c|c|c|c|c|c|c|c|c|}
\hline & \multicolumn{2}{|c|}{$\begin{array}{c}\text { Total yield } \\
\left(\mathrm{tha}^{-1} \mathrm{yr}^{-1} \mathrm{DM}\right)\end{array}$} & \multicolumn{2}{|c|}{$\begin{array}{c}\text { Sown species } \\
\text { (\% of total yield })\end{array}$} & \multicolumn{2}{|c|}{$\begin{array}{l}\text { Tanniferous species } \\
\text { (\% of total yield) }\end{array}$} & \multicolumn{2}{|c|}{$\begin{array}{l}\text { Tannin conc. of yield } \\
\left(\mathrm{g} \mathrm{CT} \mathrm{kg} \mathrm{kg}^{-1} \mathrm{DM}\right)\end{array}$} \\
\hline & Pure & Mixture & Pure & Mixture & Pure & Mixture & Pure & Mixture \\
\hline \multicolumn{9}{|l|}{ O. viciifolia ${ }^{l}$} \\
\hline Alvaschein & $11.0 \pm 0.3$ & $16.4 \pm 1.1$ & $46 \pm 8$ & $90 \pm 2$ & $46 \pm 8$ & $6 \pm 1$ & $21 \pm 4$ & $4 \pm 1$ \\
\hline Commercial seed & $11.1 \pm 0.2$ & $16.4 \pm 1.1$ & $38 \pm 13$ & $96 \pm 1$ & $38 \pm 13$ & $6 \pm 3$ & $17 \pm 3$ & $4 \pm 2$ \\
\hline Visnovsky & $13.0 \pm 1.2$ & $16.5 \pm 1.6$ & $76 \pm 6$ & $98 \pm 1$ & $76 \pm 6$ & $36 \pm 3$ & $24 \pm 2$ & $12 \pm 1$ \\
\hline \multicolumn{9}{|l|}{ L. pedunculatus ${ }^{I}$} \\
\hline Maku & $7.7 \pm 0.3$ & $18.1 \pm 1.0$ & $19 \pm 3$ & $88 \pm 1$ & $19 \pm 3$ & $5 \pm 2$ & $13 \pm 3$ & $4 \pm 1$ \\
\hline Barsilvi & $9.0 \pm 1.1$ & $17.1 \pm 0.1$ & $2 \pm 1$ & $76 \pm 1$ & $2 \pm 1$ & $1 \pm 1$ & $4 \pm 1$ & $1 \pm 1$ \\
\hline Sunrise & $8.6 \pm 1.1$ & $17.6 \pm 1.0$ & $5 \pm 1$ & $83 \pm 3$ & $5 \pm 2$ & $1 \pm 1$ & $5 \pm 1$ & $2 \pm 1$ \\
\hline \multicolumn{9}{|l|}{ L. corniculatus ${ }^{l}$} \\
\hline Odenwälder & $9.9 \pm 1.0$ & $18.0 \pm 1.2$ & $70 \pm 12$ & $95 \pm 3$ & $70 \pm 12$ & $21 \pm 9$ & $17 \pm 1$ & $6 \pm 1$ \\
\hline Lotar & $11.0 \pm 1.0$ & $18.4 \pm 1.1$ & $77 \pm 5$ & $97 \pm 1$ & $77 \pm 5$ & $32 \pm 9$ & $18 \pm 2$ & $10 \pm 2$ \\
\hline Oberhaunstädter & $10.0 \pm 1.5$ & $17.3 \pm 1.1$ & $77 \pm 6$ & $89 \pm 4$ & $77 \pm 6$ & $39 \pm 10$ & $15 \pm 1$ & $8 \pm 1$ \\
\hline \multicolumn{9}{|l|}{ C. intybus ${ }^{2}$} \\
\hline Puna & $12.8 \pm 1.0$ & $12.8 \pm 0.6$ & $100 \pm 0$ & $100 \pm 1$ & $100 \pm 1$ & $94 \pm 2$ & $5 \pm 1$ & $4 \pm 1$ \\
\hline Forage Feast & $9.9 \pm 0.5$ & $12.6 \pm 0.7$ & $99 \pm 1$ & $98 \pm 2$ & $99 \pm 1$ & $72 \pm 9$ & $5 \pm 1$ & $3 \pm 1$ \\
\hline Lacerta & $12.1 \pm 1.2$ & $12.5 \pm 1.5$ & $100 \pm 0$ & $100 \pm 1$ & $100 \pm 1$ & $87 \pm 1$ & $2 \pm 1$ & $3 \pm 1$ \\
\hline \multicolumn{9}{|l|}{$F$. pratensis } \\
\hline Preval $^{2}$ & $13.8 \pm 0.8$ & - & $92 \pm 2$ & - & - & - & - & - \\
\hline Preval $^{l}$ & $14.2 \pm 1.2$ & - & $82 \pm 1$ & - & - & - & - & - \\
\hline
\end{tabular}

$100 \mathrm{~kg} \mathrm{~N} \mathrm{yr}^{-1}$

$200 \mathrm{~kg} \mathrm{Nyr}^{-1}$.

16:00 h. The daily palatability index [PI; equation (2)] was calculated according to the following formula ${ }^{51}$ :

$$
\mathrm{PI}(t)=I_{\mathrm{T}}(t) / I_{\mathrm{C}}(t) \times 100
$$

where $I_{\mathrm{T}}(t)$ corresponds to the intake of the tanniferous forage eaten during the first $t$ minutes divided by the total intake of tanniferous plants until 16:00 h. Analogously, $I_{\mathrm{C}}(t)$ refers to the intake of the control forage eaten during the first $t$ minutes divided by the total intake of the control forage until 16:00 h. The palatability index assumes that forage selection and intake rates at the beginning of a meal are good criteria to determine palatability of forage. The palatability index exceeds $100 \%$ when the percentage of the daily-consumed tanniferous forage already eaten after $t$ minutes is larger than the corresponding percentage of the control forage. The palatability of the non-tanniferous control feed is defined as $100 \%$, and tanniferous forages for which the palatability index exceeds $100 \%$ are more palatable than the control feed.

\section{Antiparasitic activity of $\mathrm{O}$. viciifolia hay or silage}

The present feeding experiment aimed to assess the efficacy of dried or ensiled forage of $O$. viciifolia against gastrointestinal nematodes in sheep. Twenty-four Swiss white alpine $\times$ Swiss Black-Brown Mountain lambs (10 females and 14 males) were artificially infected with a single dose of $C$. curticei and $H$. contortus larvae. The lambs were between 2.5 and 3 months old and had a mean liveweight of $33 \mathrm{~kg}$ at the start of the experiment. Twentyeight days post infection, the lambs were allocated to four comparable groups according to sex, bodyweight and fecal egg counts. For 16 days, the lambs were fed ad libitum with either $O$. viciifolia or a corresponding isoproteic and isoenergetic non-tanniferous control forage each as regular hay or silage, respectively. Fecal egg counts per gram dry feces were performed twice a week. Tannin concentrations of the forages were analyzed using a butanol-HCL assay with a L. pedunculatus standard ${ }^{49}$.

\section{Results and Discussion}

\section{Agronomic performance of tanniferous forage plants}

O. viciifolia, L. corniculatus and C. intybus germinated and established well in 2004. In contrast, all cultivars of L. pedunculatus were soon outcompeted after an initially promising germination, mainly by unsown Trifolium repens. As a result, the DM proportions of $L$. pedunculatus were below 20\% DM of the accumulated yield in 2005 (four harvests) for any of the cultivars even when they were sown as a monoculture (Table 1). Therefore, the following text will concentrate on results of $O$. viciifolia, L. corniculatus and C. intybus only. 
The cultivars of $O$. viciifolia, L. corniculatus and C. intybus yielded between 9.9 and $13.0 \mathrm{tDM} \mathrm{ha}^{-1} \mathrm{yr}^{-1}$ when sown in a monoculture (Table 1). Sowing the tanniferous plants in a mixture with $F$. pratensis increased the total yield markedly in the case of $O$. viciifolia (yields of mixtures ranged from 16.4 to $16.5 \mathrm{tDM} \mathrm{ha}^{-1} \mathrm{yr}^{-1}$ ), and even more so in L. corniculatus (yields of mixtures ranged from 17.3 to $18.4 \mathrm{tDM} \mathrm{ha}^{-1} \mathrm{yr}^{-1}$ ) but only slightly in C. intybus (yields of mixtures ranged from 12.5 and $\left.12.8 \mathrm{tDM} \mathrm{ha}^{-1} \mathrm{yr}^{-1}\right)$. In the case of $O$. viciifolia and $L$. corniculatus, yields of mixtures clearly exceeded the yields of both the respective monocultures of the tanniferous plant species as well as that of the grass monoculture. This transgressive overyielding resulted most likely from $\mathrm{N}_{2}$-fixation ${ }^{52}$ of the tanniferous legume species and from a spatial and temporal niche complementation with regard to growth.

For $O$. viciifolia, $L$. corniculatus and $C$. intybus, DM proportions of sown species in the yield ranged from 38 to $100 \%$ when the tanniferous cultivars were sown in a monoculture but between 89 and 100\% when they were sown in a mixture with $F$. pratensis (Table 1 ). In other words, $F$. pratensis helped to reduce the invasion of weed and other unsown species both in terms of absolute and relative amounts of weed. However, the grass also reduced the proportion of sown tanniferous plant material in the harvest from $38-100 \%$ in monoculture to $6-94 \%$ in mixtures and, as a consequence, tannin concentrations in the harvest of mixtures were diluted accordingly (Table 1). Between species, differences in tannin concentrations at the yield level (Table 1) were much smaller than might have been expected from tannin concentrations of the tanniferous species alone (Fig. 1). While the yield of species with high tannin concentrations (i.e. $O$. viciifolia and $L$. pedunculatus) was at times heavily diluted by nontanniferous plant material, this dilution was less severe in L. corniculatus, which has intermediate tannin concentrations and almost non-existent in the case of $C$. intybus, which has very low tannin concentrations.

Cultivar Visnovsky was clearly the most promising among the tested $O$. viciifolia cultivars. Visnovsky had the highest yield (when sown as a monoculture: 13.0; when sown as a mixture: $\left.16.5 \mathrm{tha}^{-1} \mathrm{yr}^{-1} \mathrm{DM}\right)$ and the highest DM proportions of the sown plant species (monoculture: 76, mixture: $98 \% \mathrm{DM}$ ), the highest DM proportion of tanniferous plant material in the yield (monoculture: 76, mixture: $36 \% \mathrm{DM}$ ) and therefore also the highest tannin concentrations (monoculture: 24 , mixture: $12 \mathrm{~g} \mathrm{~kg}^{-1} \mathrm{DM}$ ). For L. corniculatus, cultivar Lotar performed slightly better than cv. Oberhaunstädter and cv. Odenwälder. Lotar achieved a yield of $11.0 \mathrm{tha}^{-1} \mathrm{yr}^{-1}$ in monoculture and $18.4 \mathrm{tha}^{-1} \mathrm{yr}^{-1}$ in a mixture with $F$. pratensis. The proportion of tanniferous plants was $77 \%$ in monoculture and $32 \%$ when sown in a mixture and the tannin concentration of the yield (monoculture: 18, mixture: $10 \mathrm{~g} \mathrm{~kg}^{-1} \mathrm{DM}$ ) was only slightly lower than in $O$. viciifolia. Among the tested cultivars of $C$. intybus, the cultivar Puna

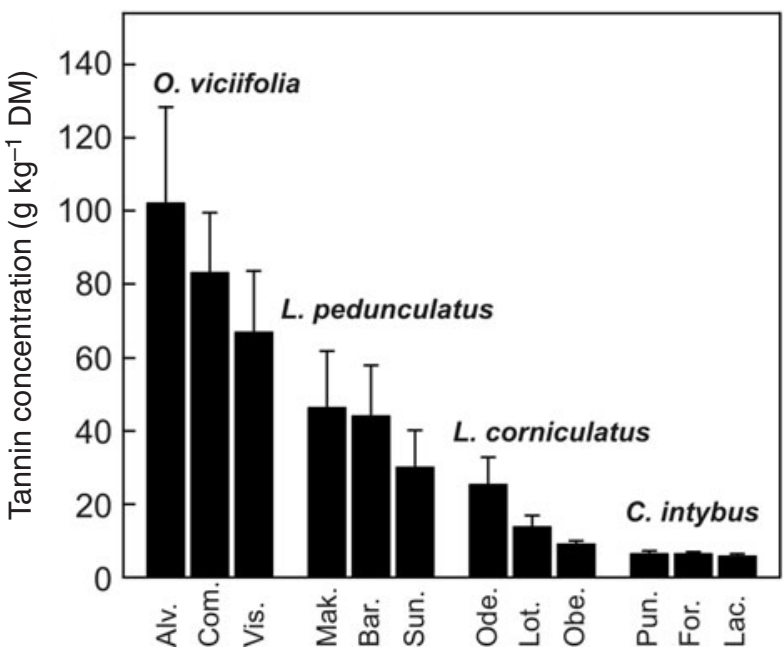

Figure 1. Tannin concentrations of harvestable aboveground biomass ( $>7 \mathrm{~cm}$; mean $\pm \mathrm{SE}$; $n=3$ ) of 12 field-grown tanniferous cultivars: $O$. viciifolia: ecotype Alvaschein (Alv.), commercial seed (Com.), cv. Visnovsky (Vis.). L. pedunculatus: cv. Grasslands Maku (Mak.), cv. Barsilvi (Bar.), cv. Grasslands Sunrise (Sun.). L. corniculatus: cv. Odenwälder (Ode.), cv. Lotar (Lot.), cv. Oberhaunstädter (Obe.). C. intybus: cv. Grasslands Puna (Pun.), cv. Forage Feast (For.), cv. INIA Lacerta (Lac.). All cultivars were collected on 8 May 2006.

clearly performed best. The other cultivars produced a large amount of stems, especially in the second year, adding to the DM yield and the DM yield proportions but supposedly reducing the forage quality.

Figure 2 displays the DM proportion of tanniferous plant material in each harvest and the corresponding tannin concentration for the most promising species and cultivars in this study (i.e. O. viciifolia cv. Visnovsky and L. corniculatus cv. Lotar). In both purely sown and mixed stands of $O$. viciifolia or $L$. corniculatus, respectively, fluctuations of DM proportions between tanniferous plants and non-tanniferous plant species were considerable. For example, in monocultures of $O$. viciifolia cv. Visnovsky, the proportion of tanniferous plants was $80 \%$ in August 2004, decreased to 55\% DM in October of the same year but recovered to almost 100\% DM in July of the following year. Shifts in the relative contribution of tanniferous plant material to total yield were reflected in the seasonal dynamics of tannin concentrations in the harvest. Therefore, we conclude that shifts in DM proportions and the competitive abilities of the tanniferous plant species are major drivers of seasonal fluctuations of tannin concentrations in the harvest.

\section{Feed palatability}

$O$. viciifolia had the highest concentration of condensed tannins, followed by L. corniculatus, while the tannin concentration of $C$. intybus was low. For all the investigated plant species, tannin concentrations $\left(\mathrm{g} \mathrm{kg}^{-1} \mathrm{DM}\right)$ were higher in silage (O. viciifolia: $100 ;$ L. corniculatus: 41; 


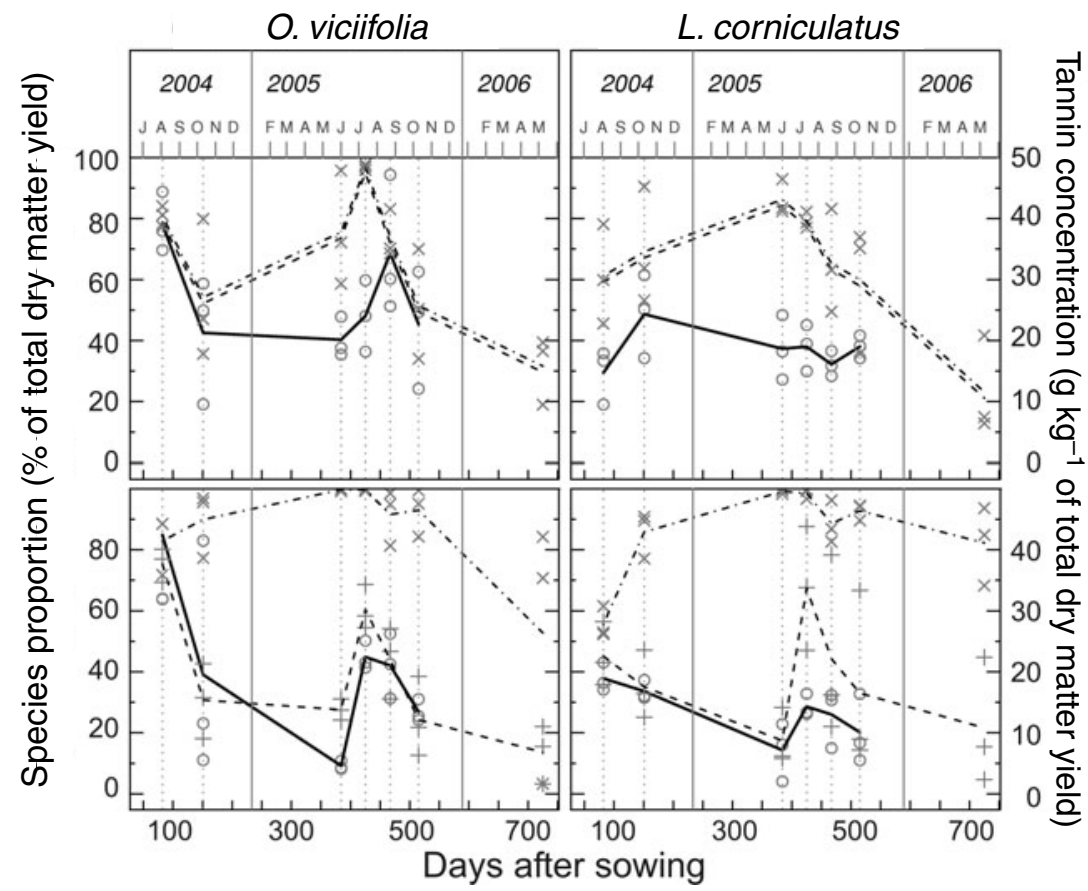

Figure 2. Mean proportion of sown species (dash-dotted line, $n=3$ ), mean proportion of tanniferous species (dashed line, $n=3$ ) as a percentage of the total DM yield, respectively, and the mean tannin concentration of individual yields (solid line, $n=3$ ) in the course of the experiment. Upper row: purely sown stands of $O$. viciifolia cv. Visnovsky, L. corniculatus cv. Lotar. Lower row: the same species and cultivars as above but sown in a mixture with the grass $F$. pratensis. Original data on the plot level are presented as symbols (i.e. $x=$ sown species, $+=$ tanniferous species, $\bigcirc=$ tannin concentration).

C. intybus: 14) than in dried plant material (O. viciifolia: 92; L. corniculatus: 26; C. intybus: 11$)$.

Offered as dried forages (Fig. 3a), palatability indices during the first 10 days were higher for O. viciifolia (PI: $91.2 \pm 23.9 \%$ ) and C. intybus (PI: $84.3 \pm 23.0 \%$ ) than for L. corniculatus (PI: $65.5 \pm 21.8 \%$ ). However, mainly due to very low initial values, none of the tanniferous forages was as palatable as the control forage when averaged over the first 10 days (the PI of the control is defined as 100\%). By increasing the energy and nutrient supply 10 days after the start of the experiment, we expected the wethers to indicate the palatabilities of the different feeds more differentiatedly. However, during the second 10 days, the palatability indices of all the tanniferous forages approximated that of the control (i.e. 100\%) to an even greater extent (average PI: O. viciifolia: $95.6 \pm 2.9 \%$; C. intybus: $102.9 \pm 13.5 \%$; L. corniculatus: $100.2 \pm 13.1 \%$ ). Hence, the palatability of the dried tanniferous forages was very similar to that of the dried ryegrass/clover mixture.

Fed as ensiled forages (Fig. 3b), the palatabilities of O. viciifolia $(151.9 \pm 81.9 \%)$ and C. intybus $(121.2 \pm 69.0 \%)$ were clearly higher than that of the control feed during the first 10 days of the experiment. Only L. corniculatus (PI: $77.7 \pm 33.3 \%$ ) had a palatability index lower than the ensiled control forage. During the second 10 days, $O$. viciifolia (on average: $159.6 \pm 51.2 \%$ ) remained more palatable than the control forage. Palatability of $C$. intybus $(100.6 \pm 16.2 \%)$ and L. corniculatus (101.0 $\pm 44.5 \%)$, however, were similar to that of the control forage.
The average palatability indices showed a high variation both among individual animals and between days. This variation was greater for ensiled than for dried forages, possibly due to the shorter evaluation time for the ensiled forage $(7.5 \mathrm{~min}$ for ensiled forages versus $15 \mathrm{~min}$ for dried forages). In the case of dried tanniferous forages, palatability was initially low compared to controls. Already 2-3 days after the start of the experiment, however, the palatability of dried tanniferous forages did not differ from that of the familiar non-tanniferous control forage. Within this short period of time, adaptations in the wether's physiology or rumen flora, to avoid potentially detrimental effects of condensed tannins, are highly unlikely. It seems more plausible that the initially low but strongly increasing palatability indices indicate beneficial postingestive feedbacks or simply reflect a sensory customization to the unfamiliar diets. Wethers needed no time to become accustomed to ensiled tanniferous forages. They were at least as palatable as the control feed immediately after the start of the experiment.

It is concluded that after 2-3 days, and independent of the conservation method used, all tested tanniferous forage plants were at least similarly palatable as an equally conserved ryegrass/clover mixture. Ensiled $O$. viciifolia had the highest tannin concentrations of all the tested diets and regardless of its elevated tannin concentrations was clearly more palatable to the wethers than an ensiled ryegrass/clover mixture. Therefore, $O$. viciifolia, especially in its ensiled form, is considered the most promising 


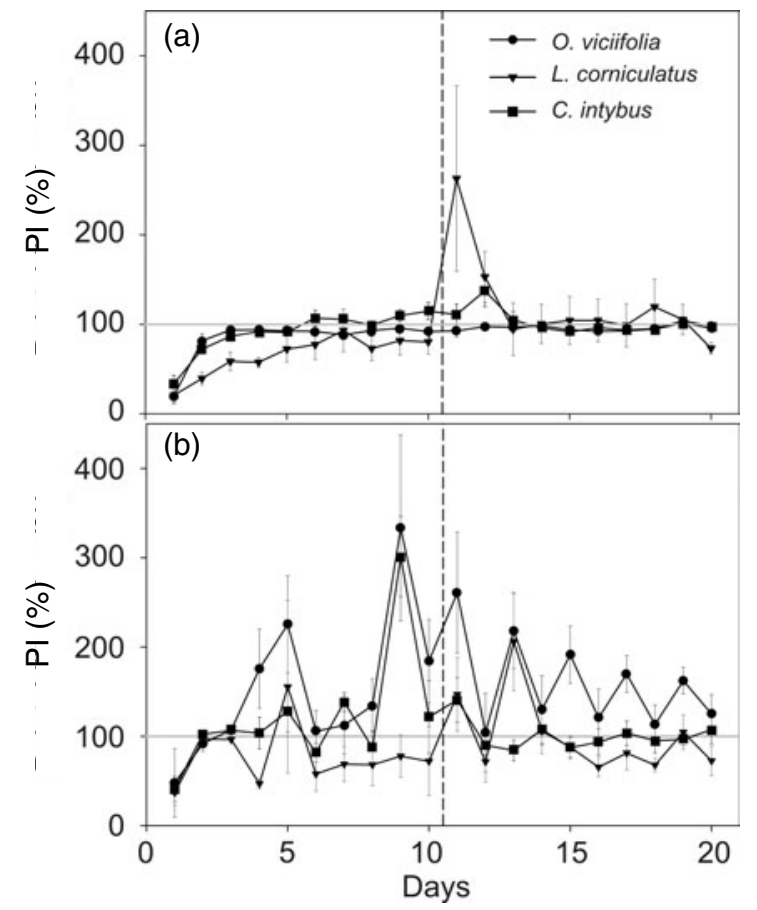

Figure 3. Palatability indices (PIs) of (a) dried or (b) ensiled tanniferous forage plants compared to a dried or ensiled nontanniferous ryegrass/clover mixture (control), respectively. The palatability index of the control is defined as $100 \%$. Tanniferous forages for which the palatability index exceeds $100 \%$ are more palatable to wethers than the control. From day 1 to 10 , feeds covered $110 \%$ of the maintenance energy requirement. After day 10 (dashed line), energy supply was increased to $155 \%$ of the maintenance energy requirement (see the Methods section).

candidate for a practical application against gastrointestinal nematodes.

\section{Antiparasitic activity of $\mathrm{O}$. viciifolia hay or silage}

The tannin concentrations of $O$. viciifolia hay and silage were $62 \mathrm{~g} \mathrm{~kg}^{-1} \mathrm{DM}$ and $41 \mathrm{~g} \mathrm{~kg}^{-1} \mathrm{DM}$, respectively. Compared to their respective control groups, marked reductions in the combined fecal egg counts of $H$. contortus and C. curtice $i$ were observed when $O$. viciifolia was fed as hay or silage (Fig. 4). Within the 16-day feeding period, fecal egg counts decreased by 58\% when lambs were fed with $O$. viciifolia hay, whereas fecal egg counts increased by $43 \%$ when lambs were fed with the control hay. For O. viciifolia silage, faecal egg counts were reduced by $37 \%$, whereas in the corresponding control group fecal egg counts increased by $16 \%$.

In comparison to the results of freshly administered $O$. viciifolia ${ }^{53}$, the antiparasitic properties of $O$. viciifolia were largely preserved in both silage and hay, leading to a substantial decrease in worm egg excretion in feces. Our results suggest that the ensuing pasture contamination with infective larvae will decrease considerably and reinfections will be reduced when sheep are fed with O. viciifolia.

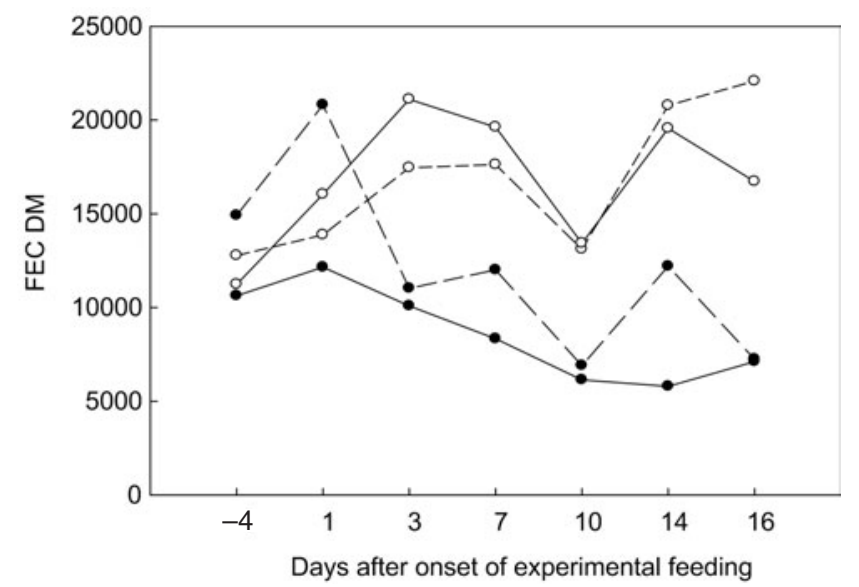

Figure 4. Mean parasite egg counts per gram dried feces (FEC $\mathrm{DM} ; n=6$ ) of lambs either fed with $O$. viciifolia (closed symbols) or non-tanniferous control forage (open symbols), each administered as hay (dashed line) or silage (solid line), respectively.

\section{Synthesis}

O. viciifolia (cv. Visnovsky), L. corniculatus (cv. Lotar) and $C$. intybus (cv. Grasslands Puna) appeared particularly suitable for cultivation under the given temperate climatic conditions, whereas $L$. pedunculatus was competitively weak, possibly because this species prefers more humid than 'average' agronomic conditions. Similar performances of these species have been observed in an independent cultivation trial at Frick, Switzerland ${ }^{53}$. With regard to their tannin concentrations, only $O$. viciifolia and L. corniculatus seemed promising candidates for the control of gastrointestinal nematodes in ruminants, whereas tannin concentrations of $C$. intybus were very low. Nevertheless, $C$. intybus has repeatedly been reported to have anthelmintic and other desirable properties possibly related to elevated concentrations of other secondary metabolites (e.g. sesquiterpene lactones) found in this species ${ }^{3}$.

Our field experiment demonstrated that the competitive ability of even the most promising tanniferous candidate plants (i.e. O. viciifolia cv. Visnovsky and L. corniculatus cv. Lotar) was suboptimal. As a consequence, seasonal fluctuations of tannin concentrations can, to a large extent, be attributed to shifts in the relative contribution of tanniferous plant material to total yield, even in purely sown swards. Pronounced short-term fluctuations in tannin concentrations of harvestable biomass (e.g. O. viciifolia, $+79 \%$ within 17 days) ${ }^{53}$ can result from differences in momentary growth rates between sown tanniferous plant species and their (sown or unsown) non-tanniferous neighbors. Additionally, fluctuations of tannin concentrations in pure stands can result from shifts in leaf/stem ratios of tanniferous forage plants during their development ${ }^{14}$. This implies that with regard to the suggested breeding of tannin-rich plants ${ }^{1}$, a high competitive ability and a large leaf to stem ratio ${ }^{14}$ are parameters likely to be just as important in enhancing the tannin concentration of 
harvestable biomass as an elevated intrinsic tannin concentration of the leaves of a cultivar.

With regard to the cultivation and management of tanniferous forage plants, mixtures were found to have clear advantages in relation to the total DM yield and in suppression of unsown species. Future research should focus on how to profit from the advantages of mixtures without suppressing tanniferous plants and lowering tannin concentrations. Possible options are (i) to lower nitrogen input to increase the competitive advantage of the tanniferous legume relative to the grass competitor, (ii) to reduce sowing densities of the grass, or (iii) to test mixtures with other grasses (e.g. short-bladed and slow-establishing grasses such as Agrostis alba or Festuca rubra). Alternatively, one could try to enhance the performance and reduce weed invasion in monocultures of tanniferous forages, for example (iv) by increasing sowing densities or (v) by adapting cutting frequencies to the tanniferous species.

Parallel to optimizing the cultivation and concentration of condensed tannins in the target candidates, investigations on the acceptance of these plants by sheep are of major importance. The feeding and palatability experiment showed that 2-3 days after the start of the experiment, the palatability of tanniferous forages was at least similar to a ryegrass/clover control, independent of the conservation method used. Regardless of its comparatively high tannin concentration, ensiled $O$. viciifolia was the most palatable among the tested forages. There was no evidence of negative side effects on the wethers from any of the tanniferous forages. Across species, the palatability of the different forages appeared unrelated to their tannin concentrations. If condensed tannins as 'plant defensive compounds, $15,17,18$ should deter herbivores, they do not seem to have acted through a depressing effect on palatability or short-term physiological feedbacks in our experiment. It is also possible that the apparent lack of a 'plant defensive effect' of condensed tannin in this study was caused by interactions with other nutrients ${ }^{11,54}$ or different chemical structures and 'potency' of tannins in the tested plant species 5 . In this context, the multitude of potentially influential chemical features of tannins and the great variety of suggested methods to analyze them contrasts with the fact that we still lack a simple but useful principle to interlink the chemical structure and the biological activity of tannins $5,11,55$.

Apart from the general interest in the potential advantages and disadvantages of tanniferous forages for ruminant metabolism, the present study was primarily aimed at preparing a pathway towards their use against gastrointestinal nematodes. Administering of hay or silage of $O$. viciifolia to lambs co-infected with $H$. contortus and C. curtice $i$ reduced the combined fecal egg output markedly compared to the controls. As trichostrongylidosis (i.e. the disease caused by gastrointestinal nematodes) is a pastureborne disease, a reduced contamination of the pasture with parasite eggs and infectious L3 larvae is likely to diminish the risk of renewed infections. Besides the effect on fecal egg output, there is strong evidence for a direct lethal effect of $O$. viciifolia on $H$. contortus ${ }^{47,53}$, the species with the highest pathogenicity among the gastrointestinal nematodes of temperate and (sub)tropical regions ${ }^{47}$.

\section{Conclusions}

The satisfactory yield and competitive ability of O. viciifolia, its high palatability despite its elevated tannin concentration and its efficacy against gastrointestinal parasites even in a conserved form would appear to make this tanniferous plant species an ideal candidate for the implementation of a non-pharmaceutical control strategy against gastrointestinal parasites. With regard to forage conservation, ensiling seems preferable to drying because it minimizes the loss of tannin-rich leaves, allows forage conservation relatively independent of the weather and, according to our results, does not diminish the palatability to sheep or the efficacy against intestinal parasites.

Further research is needed to improve our understanding of the relationship between the chemical features of the condensed tannins and their biological activity. In particular, it is essential to clarify the mode of action by which condensed tannins exert antiparasitic effects in sheep. Future studies should aim to enhance efficacy against gastrointestinal nematodes by focusing on the possibilities of increasing concentrations of condensed tannins in the offered forage without reducing the palatability or nutritional quality of the feed. Finally, a control strategy against gastrointestinal nematodes based on condensed tannins needs to be adapted to optimize its technical and economical practicability for employment and acceptance on private sheep farms.

Acknowledgements. We are particularly grateful to Hans-Ueli Briner, Bernard Papaux and Erich Rosenberg as well as to Hans-Ruedi Bosshard and Aurélia Perroud for their valuable support in the field and in the laboratory, respectively. We thank Catherine Palmer for checking the English and the Swiss Federal Office for Agriculture (BLW) for the financial support of the project.

\section{References}

1 Aerts, R.J., Barry, T.N., and Mcnabb, W.C. 1999. Polyphenols and agriculture: beneficial effects of proanthocyanidins in forages. Agriculture, Ecosystems and Environment 75(1-2):112.

2 Barry, T.N. and Mcnabb, W.C. 1999. The implications of condensed tannins on the nutritive value of temperate forages fed to ruminants. British Journal of Nutrition 81(4):263-272.

3 Hoste, H., Jackson, F., Athanasiadou, S., Thamsborg, S.M., and Hoskin, S.O. 2006. The effects of tannin-rich plants on parasitic nematodes in ruminants. Trends in Parasitology 22(6):253-261.

4 Min, B.R., Barry, T.N., Attwood, G.T., and McNabb, W.C. 2003. The effect of condensed tannins on the nutrition and 
health of ruminants fed fresh temperate forages: a review. Animal Feed Science and Technology 106(1-4):3-19.

5 Mueller-Harvey, I. 2006. Unravelling the conundrum of tannins in animal nutrition and health. Journal of the Science of Food and Agriculture 86(13):2010-2037.

6 Min, B.R., Fernandez, J.M., Barry, T.N., McNabb, W.C., and Kemp, P.D. 2001. The effect of condensed tannins in Lotus corniculatus upon reproductive efficiency and wool production in ewes during autumn. Animal Feed Science and Technology 92(3-4):185-202.

7 Ramirez-Restrepo, C. A., Barry, T.N., Lopez-Villalobos, N., Kemp, P.D., and McNabb, W.C. 2004. Use of Lotus corniculatus containing condensed tannins to increase lamb and wool production under commercial dryland farming conditions without the use of anthelmintics. Animal Feed Science and Technology 117(1-2):85-105.

8 Titus, C.H., Provenza, F.D., Perevolotsky, A., and Silanikove, N. 2000. Preferences for foods varying in macronutrients and tannins by lambs supplemented with polyethylene glycol. Journal of Animal Science 78(6):1443-1449.

9 Provenza, F.D., Villalba, J.J., Dziba, L.E., Atwood, S.B., and Banner, R.E. 2003. Linking herbivore experience, varied diets, and plant biochemical diversity. Small Ruminant Research 49(3):257-274.

10 Haslam, E. 1996. Natural polyphenols (vegetable tannins) as drugs: possible modes of action. Journal of Natural Products 59(2):205-215.

11 Waterman, P.J. and Mole, S. 1994. Analysis of Phenolic Plant Metabolites. Blackwell Scientific Publications, London.

12 Marles, M.A.S., Ray, H., and Gruber, M.Y. 2003. New perspectives on proanthocyanidin biochemistry and molecular regulation. Phytochemistry 64(2):367-383.

13 Koupai-Abyazani, M.R., McCallum, J., Muir, A.D., Bohm, B.A., Towers, G.H.N., and Gruber, M.Y. 1993. Developmental changes in the composition of proanthocyanidins from leaves of sainfoin (Onobrychis viciifolia Scop) as determined by HPLC analysis. Journal of Agricultural and Food Chemistry 41(7):1066-1070.

14 Häring, D.A., Suter, D., Amrhein, N., and Lüscher, A. 2007. Biomass allocation is an important determinant of the tannin concentration in growing plants. Annals of Botany 99(1): 111-120.

15 Bryant, J.P., Chapin, F.S., and Klein, D.R. 1983. Carbon nutrient balance of boreal plants in relation to vertebrate herbivory. Oikos 40(3):357-368.

16 Coley, P.D., Bryant, J.P., and Chapin, F.S. 1985. Resource availability and plant antiherbivore defense. Science 230(4728):895-899.

17 Herms, D.A. and Mattson, W.J. 1992. The dilemma of plants-to grow or defend. Quarterly Review of Biology 67(3):283-335.

18 Stamp, N. 2003. Out of the quagmire of plant defense hypotheses. Quarterly Review of Biology 78(1):23-55.

19 Koricheva, J. 2002. Meta-analysis of sources of variation in fitness costs of plant antiherbivore defenses. Ecology 83(1):176-190.

20 Koricheva, J., Larsson, S., Haukioja, E., and Keinanen, M. 1998. Regulation of woody plant secondary metabolism by resource availability: hypothesis testing by means of metaanalysis. Oikos 83(2):212-226.

21 Borreani, G., Peiretti, P.G., and Tabacco, E. 2003. Evolution of yield and quality of sainfoin (Onobrychis viciifolia Scop.) in the spring growth cycle. Agronomie 23(3):193-201.

22 Gebrehiwot, L., Beuselinck, R.B., and Roberts, C.A. 2002. Seasonal variations in condensed tannin concentration of three Lotus species. Agronomy Journal 94:1059-1065.

23 Roberts, C.A., Beuselinck, P.R., Ellersieck, M.R., Davis, D.K., and McGraw, R.L. (1993). Quantification of tannins in birdsfoot trefoil germplasm. Crop Science 33(5):675-679.

24 Wen, L., Roberts, C.A., Williams, J.E., Kallenbach, R.L., Beuselinck, P.R., and Mcgraw, R.L. 2003. Condensed tannin concentration of rhizomatous and nonrhizomatous birdsfoot trefoil in grazed mixtures and monocultures. Crop Science 43(1):302-306.

25 Kirwan, L., Lüscher, A., Sebastià, M.T., Finn, J.A., Collins, R.P., Porqueddu, C., Helgadottir, A., Baadshaug, O.H., Brophy, C., Coran, C., Dalmannsdóttir, S., Delgado, I., Elgersma, A., Fothergill, M., Frankow-Lindberg, B.E., Golinski, P., Grieu, P., Gustavsson, A.M., Höglind, M., Huguenin-Elie, O., Iliadis, C., Jørgensen, M., Kadziuliene, Z., Karyotis, T., Lunnan, T., Malengier, M., Maltoni, S., Meyer, V., Nyfeler, D., Nykanen-Kurki, P., Parente, J., Smit, H.J., Thumm, U., and Connolly, J. 2007. Evenness drives consistent diversity effects in an intensive grassland system across 28 European sites. Journal of Ecology 95(3): 530-539.

26 Elgersma, A., Nassiri, M., and Schlepers, H. 1998. Competition in perennial ryegrass white clover mixtures under cutting. 1. Dry-matter yield, species composition and nitrogen fixation. Grass and Forage Science 53(4):353-366.

27 Baumont, R. 1996. Palatability and feeding behaviour in ruminants. A review. Annales De Zootechnie 45(5):385-400.

28 Provenza, F.D. 1995. Postingestive feedback as an elementary determinant of food preference and intake in ruminants. Journal of Range Management 48(1):2-17.

29 Scott, L.L. and Provenza, F.D. 1999. Variation in food selection among lambs: effects of basal diet and foods offered in a meal. Journal of Animal Science 77(9):2391-2397.

30 Jansman, A.J.M., Verstegen, M.W.A., Huisman, J., and Vandenberg, J.W.O. 1995. Effects of hulls of faba beans (Vicia faba L) with a low or high content of condensed tannins on the apparent ileal and fecal digestibility of nutrients and the excretion of endogenous protein in ilealdigesta and feces of pigs. Journal of Animal Science 73(1):118-127.

31 Waghorn, G.C., Shelton, I.D., McNabb, W.C., and McCutcheon, S.N. 1994. Effects of condensed tannins in Lotus pedunculatus on its nutritive-value for sheep. 2. Nitrogenous aspects. Journal of Agricultural Science 123:109-119.

32 Min, B.R., Attwood, G.T., McNabb, W.C., Molan, A.L., and Barry, T.N. 2005. The effect of condensed tannins from Lotus corniculatus on the proteolytic activities and growth of rumen bacteria. Animal Feed Science and Technology 121(1-2): 45-58.

33 McNabb, W.C., Waghorn, G.C., Barry, T.N., and Shelton, I.D. 1993. The effect of condensed tannins in Lotus pedunculatus on the digestion and metabolism of methionine, cystine and inorganic sulfur in sheep. British Journal of Nutrition 70(2):647-661.

34 Coop, R.L. and Holmes, P.H. 1996. Nutrition and parasite interaction. International Journal for Parasitology 26(8-9): 951-962. 
35 Freeland, W.J., Calcott, P.H., and Geiss, D.P. 1985. Allelochemicals, minerals and herbivore population size. Biochemical Systematics and Ecology 13:195-206.

36 Waghorn, G.C., Shelton, I.D., and McNabb, W.C. 1994. Effects of condensed tannins in Lotus pedunculatus on its nutritive-value for sheep. 1. Nonnitrogenous aspects. Journal of Agricultural Science 123:99-107.

37 Salawu, M.B., Acamovic, T., Stewart, C.S., Hvelplund, T., and Weisbjerg, M.R. 1999. The use of tannins as silage additives: effects on silage composition and mobile bag disappearance of dry matter and protein. Animal Feed Science and Technology 82(3-4):243-259.

38 Ott, E.M., Aragón, A., and Gabel, M. 2005. Ensiling of tannincontaining sorghum grain. Proceedings of the 14th International Silage Conference, 3-6 July 2005, Belfast, UK. p. 178.

39 Waller, P.J. and Thamsborg, S.M. 2004. Nematode control in 'green' ruminant production systems. Trends in Parasitology 20(10):493-497.

40 Woolaston, R.R. and Baker, R.L. 1996. Prospects of breeding small ruminants for resistance to internal parasites. International Journal for Parasitology 26(8-9):845-855.

41 Eysker, M., Bakker, N., van der Hall, Y.A., van Hecke, I., Kooyman, F.N.J., van der Linden, D., Schrama, C., and Ploeger, H.W. 2006. The impact of daily Duddingtonia flagrans application to lactating ewes on gastrointestinal nematodes infections in their lambs in the Netherlands. Veterinary Parasitology 141(1-2):91-100.

42 Larsen, M. 1999. Biological control of helminths. International Journal for Parasitology 29(1):139-146.

43 Niezen, J.H., Charleston, W.A.G., Hodgson, J., Mackay, A.D., and Leathwick, D.M. 1996. Controlling internal parasites in grazing ruminants without recourse to anthelmintics: approaches, experiences and prospects. International Journal for Parasitology 26(8-9):983-992.

44 Coop, R.L. and Kyriazakis, I. 2001. Influence of host nutrition on the development and consequences of nematode parasitism in ruminants. Trends in Parasitology 17(7):325-330.

45 Waller, P.J. 1997. Anthelmintic resistance. Veterinary Parasitology 72(3-4):391-405.

46 Molan, A.L., Meagher, L.P., Spencer, P.A., and Sivakumaran, S. 2003. Effect of flavan-3-ols on in vitro egg hatching, larval development and viability of infective larvae of Trichostrongylus colubriformis. International Journal for Parasitology 33(14):1691-1698.

47 Heckendorn, F., Häring, D.A., Maurer, V., Zinsstag, J., Langhans, W., and Hertzberg, H. 2006. Effect of sainfoin (Onobrychis viciifolia) silage and hay on established populations of Haemonchus contortus and Cooperia curticei in lambs. Veterinary Parasitology 142(3-4):293-300.

48 Gomez, K.A. and Gomez, A.A. 1984. Statistical Procedures for Agricultural Research. Wiley, New York.

49 Terrill, T.H., Rowan, A.M., Douglas, G.B., and Barry, T.N. 1992. Determination of extractable and bound condensed tannin concentrations in forage plants, protein-concentrate meals and cereal-grains. Journal of the Science of Food and Agriculture 58(3):321-329.

50 RAP (Swiss Federal Research Station for Animal Production and Dairy Products). 1999. Fütterungsempfehlungen und Nährwerttabellen für Wiederkäuer. Landwirtschaftliche Lehrmittelzentrale, Zollikofen.

51 Ben Salem, H., Nefzaoui, A., and Abdouli, H. 1994. Palatability of shrubs and fodder trees measured on sheep and dromedaries. 1. Methodological approach. Animal Feed Science and Technology 46(1-2):143-153.

52 Jacot, K.A., Lüscher, A., Nösberger, J., and Hartwig, U.A. 2000. The relative contribution of symbiotic $\mathrm{N}_{2}$ fixation and other nitrogen sources to grassland ecosystems along an altitudinal gradient in the Alps. Plant and Soil 225(1-2): 201-211.

53 Heckendorn, F., Häring, D.A., Maurer, V., Senn, M., and Hertzberg, H. 2007. Individual administration of three tanniferous forage plants to lambs artificially infected with Haemonchus contortus and Cooperia curticei. Veterinary Parasitology 146:123-134.

54 Villalba, J.J., Provenza, F.D., and Bryant, J.P. 2002. Consequences of the interaction between nutrients and plant secondary metabolites on herbivore selectivity: benefits or detriments for plants? Oikos 97(2):282-292.

55 Kraus, T.E.C., Yu, Z., Preston, C.M., Dahlgren, R.A., and Zasoski, R.J. 2003. Linking chemical reactivity and protein precipitation to structural characteristics of foliar tannins. Journal of Chemical Ecology 29(3):703-730. 